\title{
Studies on Genotypic and Phenotypic Correlation Coefficient of Different Clones of Eucalyptus (Eucalyptus tereticornis Sm)
}

\author{
J.M. Bhatti ${ }^{1}$, Y.Y. Sumthane ${ }^{2 *}$, A.U. Nimkar ${ }^{2}$, N. K. Kapse ${ }^{2}$ and Y.B. Tayde ${ }^{2}$ \\ ${ }^{1}$ Department of Forestry, Dr. Panjabrao Deshmukh Krishi Vidyapeeth, \\ Akola (Maharashtra), India \\ ${ }^{2}$ Department of Forest Products, Dr. Y.S. Parmar University of Horticulture and Forestry, \\ Nauni (Solan) 173 230, H.P, India \\ *Corresponding author
}

\begin{tabular}{|l|}
\hline K e y w o r d s \\
Correlation, \\
Coefficient, \\
Volume, Exhibited, \\
Phenotypic, \\
Genotypic \\
\hline Article Info \\
\hline $\begin{array}{l}\text { Accepted: } \\
\text { 24 June 2018 } \\
\text { Available Online: } \\
\text { 10 July 2018 }\end{array}$ \\
\hline
\end{tabular}

\section{Introduction}

Eucalyptus tereticornis has increasingly become the most widely planted, hardwood genus in the world (Turnbull, 1999). Eucalyptus tereticornis provide sawn timber, mine props, paper, pulp, fiber board, poles, firewood, charcoal, essential oils, honey, and tannin products. Eucalyptus tereticornis plantation growth rate is an important economic factor as fast growing trees will be available for processing earlier compared to slower growing trees. Tree growth and the ultimate production of wood is a product of the interaction of genetic, silvicultural and environmental factors (Kozlowski and Pallardy, 1997) (Pallett and Sale, 2004) (Drew and Pammenter, 2006). The present status of eucalyptus in India is, there are some 170 species, varieties and provenances of eucalyptus were tried in India, out of which the most outstanding and favoured has been the E. hybrid, a form of E. tereticornis known as Mysore gum.

In Maharashtra the Forest Department started raising large scale plantations of eucalyptus from 1961 onwards; over 150,000 ha of 
Eucalyptus plantations exist. The main species raised are E. hybrid and E. camaldulensis in the dry zone. In high rainfall areas Eucalyptus grandis followed by E. robustaand Eucalyptus saligna were found to be more suitable and in Goa, Daman \& Diu during since 1963, some 5,000 ha of Eucalyptus plantations were raised to meet the shortage of fire wood. These clones were grown by Industrial corridor to utilize the pulp as a row material for paper making. The climatic and geographic conditions are satiable to this species in these semi-arid climatic reasons.

\section{Materials and Methods}

The present investigation was carried out with ten clones of Eucalyptus (Eucalyptus tereticornis Sm.) at Department of Forestry, Dr.Panjabrao Deshmukh KrishiVidyapeeth, Akola and the observations were taken from Eucalyptus clonal plantation in Yavatmal district established by Ballarpur Paper Industry Limited, Ballarpur, Maharashtra. The clones under study belonging to same age group. The soil of experimental site belongs to red sandy and shallow black soil depth is up to 1 to $1.5 \mathrm{~m}$.

\section{Climate and weather conditions}

Eucalyptus clonal plantation in Yavatmal district is situated at a distance of $3 \mathrm{Km}$ from Yavatmal in Eastern direction of YavatmalChandrapur Highway. The research station falls under the agro-climatic zone number IX north latitude at $20^{\circ} 24^{\prime} \mathrm{N}$ and $78^{\circ} 08^{\prime} \mathrm{E}$ longitude. The average range of temperature is $23.6^{\circ} \mathrm{C}$ to $38.6^{\circ} \mathrm{C}$ with mean annual rainfall of $886.4 \mathrm{~mm}$.

\section{Quantitative characters}

The observations of quantitative characters were recorded on one randomly selected plant for each clone to representing treatment mean for that replication. Plant height (m):Plant height of randomly selected clone per replication was recorded in meter by using the altimeter. Girth (m): Girth of each clone was recorded from $1.37 \mathrm{~m}$ above the ground level at breast height in meter by using the measuring tape. Leaf area $\left(\mathrm{cm}^{2}\right)$ :The leaves from the plants are separated and grouped into small, medium and large. One representative leaf from each group is inserted in leaf area meter. The instrument gives the direct leaf area reading. From this reading the total leaf area can be calculated. Dry weight of leaf (g):Dry weight of leaf of each clone was measured in hot air oven at the temperature of $80^{\circ}$ for 4 hours in $\mathrm{g}$. Number of branches:Numbers of primary branches of each clone were counted manually for each clone per replication. Volume $\left(\mathrm{m}^{3}\right)$ :Volumeof each genotype was calculated by using the quarter girth formula given by Hoppu's rule (Chaturvedi et al., 1991).

\section{Analysis of variance for various characters}

The analysis of variance was carried out to test the significance of difference between the clones for the characters under study as per the standard method given by Panse and Sukhatme (1954) and Singh and Chaudhary (1977).Based on above model, the table of analysis of variance (ANOVA) was setup and data was analysed. ' $F$ ' test was used to measure the significance of the differences among the clones. The standard error of differences S.E. (d) and critical difference (C.D.) between two means were also calculated for treatment comparison.

\section{Analysis of covariance}

Fisher and Yates (1958) suggested a method for partitioning the variance and covariance into its heritable and non-heritable components as per below. 
i) Genotypic variance

$$
\sigma^{2} g=\frac{M S g-M S e}{r}
$$

ii) Phenotypic variance

iii) Environmental variance

$$
\sigma^{2} p=\sigma^{2} g+M S e
$$

The genotypic, phenotypic and environmental covariance's were estimated on similar lines.

$$
\sigma^{2} e=M S e
$$

\section{Variability parameters studies}

It was estimated by the formula given by Burton (1952)

$$
\text { G.C.V. }=\frac{\sqrt{\text { Genotypic variance }}}{\bar{X}} \times 100
$$$$
\text { P.C.V. }=\frac{\sqrt{\text { Phenotypic variance }}}{\bar{X}} \times 100
$$

$\bar{X}=$ Mean of the character

G.C.V. = Genotypic coefficient of variation P.C.V. = Phenotypic coefficient of variation

\section{Results and Discussion}

\section{Correlation}

The genotypic and phenotypic correlation, correlation coefficient among the different characters has been presented in Table 1 . Mean performance of eucalyptus clones for

\begin{tabular}{|c|c|c|c|c|c|c|c|}
\hline $\begin{array}{l}\text { Serial } \\
\text { Number }\end{array}$ & $\begin{array}{l}\text { Treatments } \\
\text { (Clones) }\end{array}$ & $\begin{array}{l}\text { Plant } \\
\text { height } \\
\text { (m) }\end{array}$ & $\begin{array}{l}\text { Plant } \\
\text { girth } \\
\text { (m) }\end{array}$ & $\begin{array}{l}\text { Leaf area } \\
\left(\mathbf{c m}^{2}\right)\end{array}$ & $\begin{array}{l}\text { Dry weight } \\
\text { of leaves } \\
\text { (g) }\end{array}$ & $\begin{array}{l}\text { Number of } \\
\text { branches }\end{array}$ & $\begin{array}{l}\text { Volume } \\
\left(\mathbf{m}^{3}\right)\end{array}$ \\
\hline 1 & 316 & 14.21 & 0.48 & 64.70 & 0.44 & 13.33 & 0.21 \\
\hline 2 & 288 & 13.52 & 0.39 & 57.47 & 0.38 & 13.67 & 0.13 \\
\hline 3 & 526 & 14.06 & 0.41 & 54.70 & 0.37 & 11.00 & 0.15 \\
\hline 4 & 413 & 14.65 & 0.43 & 61.33 & 0.41 & 12.33 & 0.17 \\
\hline 5 & 07 & 14.17 & 0.47 & 71.57 & 0.50 & 13.33 & 0.19 \\
\hline 6 & 2030 & 14.90 & 0.48 & 56.57 & 0.37 & 13.67 & 0.21 \\
\hline 7 & 415 & 14.31 & 0.40 & 69.07 & 0.48 & 13.33 & 0.15 \\
\hline 8 & 2070 & 14.75 & 0.41 & 56.43 & 0.38 & 12.67 & 0.16 \\
\hline 9 & 2130 & 14.13 & 0.43 & 62.03 & 0.41 & 14.00 & 0.16 \\
\hline \multirow[t]{6}{*}{10} & 411 & 14.72 & 0.41 & 61.53 & 0.41 & 13.33 & 0.15 \\
\hline & Mean & 14.34 & 0.43 & 61.54 & 0.42 & 13.07 & 0.17 \\
\hline & Rang & $\begin{array}{l}13.52- \\
14.90\end{array}$ & $\begin{array}{l}0.39- \\
0.48\end{array}$ & $\begin{array}{l}54.47- \\
71.57\end{array}$ & $0.37-0.50$ & $11.00-14.00$ & $0.13-0.20$ \\
\hline & $\operatorname{Se}(\mathrm{m})$ & 0.25016 & 0.0194 & 1.75754 & 0.01549 & 0.40521 & 0.01708 \\
\hline & $\mathrm{CV}$ & 3.0214 & 7.8089 & 4.9466 & 6.4382 & 5.3713 & 17.536 \\
\hline & $\mathrm{Cd} 5 \%$ & 0.7433 & 0.0576 & 5.22212 & 0.04602 & 1.20399 & 0.05074 \\
\hline
\end{tabular}
selected quantitative traits.

Table.1 Genotypic and phenotypic correlation and correlation coefficient among the different characters 
Table.2 Analysis of variance of selected quantitative traits in eucalyptus

\begin{tabular}{|l|c|c|c|c|c|c|c|}
\hline \multicolumn{1}{|c|}{$\begin{array}{c}\text { Sources of } \\
\text { variation }\end{array}$} & $\begin{array}{c}\text { Degree } \\
\text { of } \\
\text { freedom }\end{array}$ & $\begin{array}{c}\text { Plant } \\
\text { height } \\
(\mathrm{m})\end{array}$ & $\begin{array}{c}\text { Girth } \\
(\mathrm{m})\end{array}$ & $\begin{array}{c}\text { Leaf area } \\
\left(\mathrm{cm}^{2}\right)\end{array}$ & $\begin{array}{c}\text { Dry } \\
\text { weight of } \\
\text { leaf }(\mathrm{g})\end{array}$ & $\begin{array}{c}\text { Number } \\
\text { of } \\
\text { branches }\end{array}$ & $\begin{array}{c}\text { Volume } \\
\left(\mathrm{m}^{3}\right)\end{array}$ \\
\hline Replication & 2 & 0.0872 & 0.0028 & 0.3906 & 0.00012 & 0.23333 & 0.00209 \\
\hline Treatment & 9 & $0.5229 *$ & $0.0032^{*}$ & $93.885^{* *}$ & $0.00632^{*}$ & $2.2814^{* *}$ & $0.00233^{*}$ \\
\hline Error & 18 & 0.1878 & 0.0011 & 9.266 & 0.00072 & 0.49259 & 0.00087 \\
\hline
\end{tabular}

* Significant at $5 \%$

** $\quad$ Significant at $1 \%$

Table.3 Genotypic and phenotypic correlation coefficient (r)

\begin{tabular}{|c|c|c|c|c|c|c|c|}
\hline $\begin{array}{l}\text { Sr. } \\
\text { No. }\end{array}$ & Characters & & $\begin{array}{l}\text { Girth } \\
\text { (m) }\end{array}$ & $\begin{array}{c}\text { Leaf area } \\
\left(\mathrm{cm}^{2}\right)\end{array}$ & $\begin{array}{l}\text { Dry weight } \\
\text { of leaf (g) }\end{array}$ & $\begin{array}{l}\text { Number of } \\
\text { branches }\end{array}$ & $\begin{array}{c}\text { Volume } \\
\left(\mathbf{m}^{3}\right)\end{array}$ \\
\hline \multirow[t]{2}{*}{ 1) } & \multirow[t]{2}{*}{ Plant height (m) } & G & 0.221 & -0.142 & -0.162 & -0.041 & 0.340 \\
\hline & & $\mathrm{P}$ & 0.399 & -0.056 & -0.075 & -0.048 & 0.481 \\
\hline \multirow[t]{2}{*}{ 2) } & \multirow[t]{2}{*}{ Girth (m) } & G & - & 0.297 & 0.309 & 0.296 & 0.992 \\
\hline & & $\mathrm{P}$ & - & 0.275 & 0.269 & 0.100 & 0.991 \\
\hline \multirow[t]{2}{*}{ 3) } & \multirow[t]{2}{*}{ Leaf area $\left(\mathrm{cm}^{2}\right)$} & G & & - & 0.997 & 0.399 & 0.253 \\
\hline & & $P$ & & - & 0.986 & 0.368 & 0.239 \\
\hline \multirow[t]{2}{*}{ 4) } & \multirow[t]{2}{*}{ Dry weight of leaf (g) } & $\mathrm{G}$ & & & - & 0.307 & 0.265 \\
\hline & & $\mathrm{P}$ & & & - & 0.333 & 0.232 \\
\hline \multirow[t]{2}{*}{ 5) } & \multirow[t]{2}{*}{ Number of branches } & G & & & & - & 0.344 \\
\hline & & $\mathrm{P}$ & & & & - & 0.098 \\
\hline \multirow[t]{2}{*}{ 6) } & \multirow[t]{2}{*}{ Volume $\left(\mathrm{m}^{3}\right)$} & G & & & & & - \\
\hline & & $\mathrm{P}$ & & & & & - \\
\hline & $\begin{array}{l}=\text { Significant at } 5 \% \text { lev } \\
=\text { Significant at } 1 \% \text { lev }\end{array}$ & $\begin{array}{l}(361) \\
(463)\end{array}$ & & & $\begin{aligned} \mathrm{G} & =\mathrm{Ge} \\
\mathrm{P} & =\mathrm{Ph}\end{aligned}$ & $\begin{array}{l}\text { typic correlatio } \\
\text { typic correlatic }\end{array}$ & \\
\hline
\end{tabular}


In conclusion, the genotypic and phenotypic correlation coefficient studied between stem volume and its contributing character indicated that girth exhibited positive and significant correlation with volume at phenotypic and genotypic level (Table 2 and $3)$. The girth exhibited positive and nonsignificant correlation with dry weight of leaf at genotypic and phenotypic level. Leaf area showed exhibited positive and significant correlation dry weight of leaf at genotypic and phenotypic level. Dry weight of leaf exhibited a positive and non-significant correlation with number of branches at genotypic and phenotypic level.

\section{References}

Burton GW. 1952. Quantitative in haritance in grasses, Proc. $6^{\text {th }}$ International Grassland Congress. 1: 277-283.

Chaturvedi AN. and. KhannaLS. 1991. forest mensuration. International Book Distributors, DehraDun. pp 95-100.

Drew DM and Pammenter NW. 2006. Vessel frequency, size and arrangement in two eucalypt clones growing at sites differing in water availability. New Zealand Journal of Forestry 51:23-28.

Fisher RA and Yates F. 1958. Statistical tables for biological, agricultural and medical research. $5^{\text {th }}$ edn. Hafner Publ. Co., New York.

Kozlowski TT and Pallardy SG. 1997. Physiology of Woody Plants. Second edition. San Diego: Academic Press. pp. 1-6.

Pallett RN and. Sale G. 2004.The relative contributions of tree improvement and cultural practice towards productivity gains in Eucalyptus pulpwood stands. Fort. Ecol. Manage. 193:33-43.

Panse VG. and Sukhatme PV. 1954. Statistical methods for agricultural workers, ICAR Publications. New Delhi. pp 72-96.

Singh RK and ChaudharyBD. 1977. Biometrical methods in quantitative genetic analysis, Kalyani Publishers, New Delhi. 200-223.

Turnbull JW. 1999. Eucalyptus plantations. New Forests. 17:37-52.

\section{How to cite this article:}

Bhatti, J.M., Y.Y. Sumthane, A.U. Nimkar, N. K. Kapse and Tayde, Y. B. 2018. Studies on Genotypic and Phenotypic Correlation Coefficient of Different Clones of Eucalyptus (Eucalyptus tereticornis Sm). Int.J.Curr.Microbiol.App.Sci. 7(07): 3414-3418. doi: https://doi.org/10.20546/ijcmas.2018.707.396 